\title{
CSI Accounting: A New Trend In Educational Training
}

Elizabeth C. Ekmekjian, (Email: ekmekjiane@wpunj.edu), William Paterson University Alan Drucker, (Email: Alan.Drucker@ci.irs.gov), Internal Revenue Service Hubert Klein, CPA (Email: hklein@Amper.com), Amper, Politziner \& Mattia PC Anthony Basile, (Email: Anthony.Basile@hofstra.edu), Hofstra University

\begin{abstract}
Recently, members of the Christos M. Cotsakos College of Business, Department of Accounting and Law, have been approached by IRS and accounting practitioners concerning the addition of fraud and forensic accounting courses to the curriculum. This seems to be a new trend in expanding the education and training of accounting majors as evidenced by a U.S. Department of Justice, NIJ Special Report titled, "Education and Training in Fraud and Forensic Accounting: A Guide for Educational Institutions, Stakeholder Organizations, faculty and Students." The December 20, 2005 Draft Report provides that as a result of recent corporate scandals, there has been a substantial increase in both legal and regulatory requirements. "These requirements address internal controls for detecting and deterring fraud and encourage financial statement auditors to be more aggressive in searching for fraud." Students desirous of becoming "CSI Accountants" are in need of a better understanding surrounding the field and the knowledge and skills required to succeed. This paper will begin with a brief mention of various financial scandals and certain regulatory requirements which followed. The motivation for a need for this new educational training will then be reviewed along with the problems faced by institutions of higher education when adding new courses and changing current curriculum. Finally, a brief overview of the contents of the NIJ Report will be made.
\end{abstract}

\section{FINANCIAL SCANDALS}

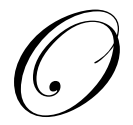

$\mathrm{n}$ any given day, a search can be performed on Google or LexisNexis where the searcher types in "financial scandals" and receives thousands of hits. They range from small town scandals (see, e.g. Residents pitch in to help town recover from financial scandal - The Associated Press State \& Local Wire, August 5, 2005), to schools (see, e.g. After the Roslyn Mess, Who Audits Schools?, The New York Times, June 19, 2005), to other non-profits (see, e.g. Nonprofits feel pinch of firmer financial rules: Strand agencies' scandals spotlight need for more scrutiny, analysts say, The Sun News (Myrtle Beach, South Carolina), November 13, 2006) to celebrities (such as Martha Stewart); to large corporations (see discussion of Enron below). These frauds are not indigenous to the United States (see, e.g. Trial dealing with Algeria's biggest financial scandal starts, Middle East and North Africa Report (Amman, Jordan), January 9, 2007; Malaysia's Bank Islam vows probe as financial scandal looms, Agence France Presse - English, October 28, 2005; and the D’Long trial, China's biggest financial scandal).

These swindles and scandals arise from fraudulent acts of trusted employees, executives, board members, accountants, lawyers, clients, etc. and include: misuse of funds, theft, inflation of profits and assets, understatement of liabilities and losses, and insider trading.

In 2001, one of the most highly profiled financial scandals of the United States was revealed. Enron Corporation, a US energy corporation, filed for bankruptcy protection after its exposure in corporate fraud. Enron's reported financial condition - including fraudulent or nonexistent assets, over-inflated profits, under-reporting of debts and losses, etc. - was the result of creative, but misleading practices by insiders and executives of Enron. In the aftermath, the Corporation went bankrupt, many employees and board members were convicted of fraud, shareholders' were devastated financially, and employees lost jobs, benefits and pension assets. 
In addition, Arthur Anderson, Enron's accounting firm, was convicted of obstruction of justice for the destruction of documents relating to the Enron audit. Upon learning that Anderson was going to be the subject of a Securities and Exchange Commission (SEC) investigation, employees were instructed to shred and destroy documents relating to Enron. This conviction led to the dissolution of Anderson, one of the fifth largest accounting firms in the United States. While the conviction was later overturned by the Supreme Court in Arthur Anderson LLP v. United States, 544 U.S. 696 (2005), as of 2007, Anderson has not re-surfaced into the accounting profession.

Enron, along with Global-Crossing, Tyco International, and the Worldcom scandals, resulted in the loss of public trust and confidence in corporate management and accounting and reporting practices. In 2002 the United States responded with the Sarbanes-Oxley Act (SOX). Its purpose is to ensure that board members and top executives of publicly held companies take responsibility for reporting accurately on its financial condition to the public. Among its many provisions, SOX establishes new responsibilities for corporate boards and audit committees; new accountability standards and criminal penalties for Mangers; new independence standards and rules of professional responsibilities for external auditors and outside counsel; and establishes a new regulatory body to oversee public company auditors (the Public Company Accounting Oversight Board - PCAOB).

\section{MOTIVATION FOR A CHANGE IN ACCOUNTING EDUCATION}

The addition of courses in fraud and forensic accounting appears to be a new trend in expanding the education and training of accounting majors as evidenced by a U.S. Department of Justice, NIJ Special Report titled, "Education and Training in Fraud and Forensic Accounting: A Guide for Educational Institutions, Stakeholder Organizations, faculty and Students." The December 20, 2005 Draft Report provides that as a result of recent corporate scandals, there has been a substantial increase in both legal and regulatory requirements. "These requirements address internal controls for detecting and deterring fraud and encourage financial statement auditors to be more aggressive in searching for fraud." Students desirous of becoming "CSI Accountants" are in need of a better understanding surrounding the field and the knowledge and skills required to succeed.

\section{CHALLENGES FACED BY COLLEGES \& UNIVERSITIES}

The creation of an accounting curriculum requires the identification of a learning objective. Typically, this objective is to prepare students to pass the certified public accountant's exam (CPA exam), and prepare them to pursue careers in public or private accounting. Answers to how that is achieved are difficult and vary from institution to institution. Each curriculum varies with the types and number of courses offered, the extent of coverage of topics, areas of concentration, and number of credits required for graduation (some schools now require accounting students to complete a five year program versus a four year schedule). For example, a comparison of two state higher education programs in New Jersey offers the following:

$\begin{array}{ll}\text { General Education } & \begin{array}{l}\text { William Paterson University (WPU) } \\ 68-69 \text { semester hours }\end{array} \\ \text { Common Business Core } & \begin{array}{l}33 \text { credits including classes in } \\ \text { financial and managerial accounting, } \\ \text { economics, finance, management, } \\ \text { marketing, information systems and } \\ \text { business law I }\end{array}\end{array}$

Major Requirements

Accounting Electives
21 credits including intermediate I and II, cost, auditing, tax I and II, advanced I, business law II or advanced II

none required - options include business law II, advanced II, internship
Montclair State University (MSU) $51-57$ semester hours

33 credits - similar requirements as WPU
15 credits including intermediate I and II, contemporary issues in intermediate, cost, advanced financial

12 credits: choice of internal auditing or auditing theory, two of the following: business law II, tax I, tax II, accounting information systems, government/NFP, and choice of two capital management courses 
As you can see, the WPU program provides very few choices in terms of accounting electives. The program is regimented towards detailed coverage of topical areas on the CPA exam. In comparison, the MSU program requires 6 additional semester hours of business courses, but students may elect to skip certain areas tested on the exam - such as taxation or contract law. This comparison illustrates some of the inconsistences adopted by accounting educators in developing academic curriculum, i.e. the number of courses required, areas of topical focus, CPA exam coverage. Neither is all inclusive, but both appear to be comprehensive.

One author presents a few additional concerns faced by the accounting educators at WPU. First, while the WPU accounting curriculum is focused on the preparing students to enter the accounting profession, it does so by incorporating requirements of the Association to Advance Collegiate Schools of Business (AACSB). Accreditation by this international organization requires satisfaction or rigorous standards which encompass course coverage in numerous academic areas. Its goal is to encourage academic excellence through quality programs and continuous improvement. Before being awarded AACSB accreditation, the Accounting \& Law Department made changes to its then current program in order to satisfy the AACSB standards. This, in effect, eliminated any choices in accounting electives.

The administrative processes implemented to make changes to a curriculum, as well as adding courses, require several layers of approval and paperwork. This often represents a challenge, particularly when competing interests are concerned. For example, if a course is going to be offered on a trial basis, it must first be approved by the department, then to the Dean of the College and then by the Provost. If added to the curriculum on a permanent basis, prior to approval by the Provost, the Faculty Senate (consisting of representatives from the entire University including four Colleges outside of the business school) must vote on the whether the course is deemed applicable. A compelling case must be presented to non-business educators and administrators who may not understand the ramifications or important of the proposal. This process may also turn into a question of politics as approval would mean that additional faculty may be needed to teach the course(s), thereby taking funding away from other programs.

Another issue that we face concerns budget constraints. As a State University, we are subjected to the mercy of the legislature as concerns funding. For example, during the 2005-2006 academic year, members of the Department of Accounting and Law were approached by IRS and accounting practitioners concerning the addition of fraud and forensic accounting courses to the curriculum. In fact, the IRS generously offered to teach a class that it had developed, free of charge (this, of course, ran into union issues as the teacher would have to be paid under the union contract - in addition, an IRS agent probably would not have satisfied the AACSB "academically or professionally qualified" standard for faculty). Initially, certain faculty members had reservations concerning any change to the program, however, the Department soon agreed that this important, hot topic should be offered to our students. The paperwork was approved by all, the State of New Jersey shut its doors during the summer of 2006 until the government balanced its budget, the University's funding was cut and so was the course!

With so many obstacles, how can we incorporate contemporary business issues and courses focused on current trends into the curriculum?

\section{NIJ SPECIAL REPORT}

The NIJ Special Report provides a guide for educational institutions in offering fraud and forensic accounting training. The development of a model curriculum geared towards building knowledge, skills and abilities is discussed and suggests that the curriculum be student driven, based on interests in differing areas of the profession. For example, model curriculum are provided for the following:

- $\quad$ Criminology, legal environment and ethics;

- $\quad$ Fraud and forensic accounting; and

- $\quad$ Forensic and litigation advisory services. 
Finally, an example of the implementation process by West Virginia University of the model curriculum for fraud and forensic accounting is provided. The report is an excellent guide and should be reviewed by accounting departments interested in learning of and/or incorporating contemporary issues into their curriculum.

\section{SUMMARY}

In response to high profile corporate fraud in the United States, far reaching and challenging legislation has been enacted - SOX. As a result, the need for educated and trained individuals to implement and ensure compliance is growing. The addition of forensic accounting courses seems to be a new trend in expanding the education of accounting majors to fill this gap. However, challenges and obstacles such as administrative processes, higher education politics, reluctance to change and budgetary issues are major threats to the continuation of this process. Will accounting educators be able to overcome these hurdles?

\section{NOTES}

